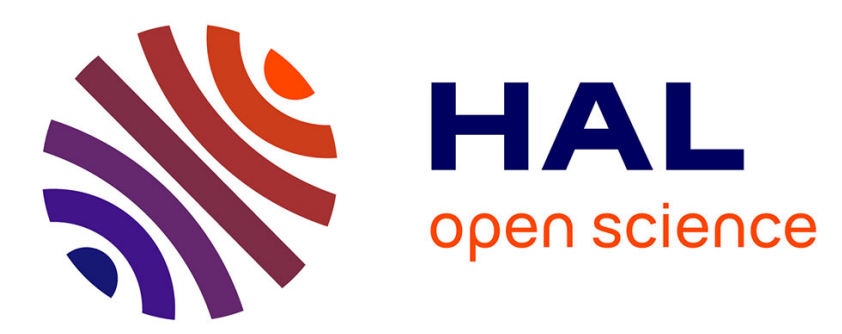

\title{
Detour and break optimising distance, a new perspective on transport and urbanism
}

\author{
Alain L'Hostis
}

\section{To cite this version:}

Alain L'Hostis. Detour and break optimising distance, a new perspective on transport and urbanism. Environment and Planning B: Planning and Design, 2017, 44 (3), pp.441-463. 10.1177/0265813516638849. hal-01179908v2

\section{HAL Id: hal-01179908 \\ https://hal.science/hal-01179908v2}

Submitted on 29 Mar 2016

HAL is a multi-disciplinary open access archive for the deposit and dissemination of scientific research documents, whether they are published or not. The documents may come from teaching and research institutions in France or abroad, or from public or private research centers.
L'archive ouverte pluridisciplinaire HAL, est destinée au dépôt et à la diffusion de documents scientifiques de niveau recherche, publiés ou non, émanant des établissements d'enseignement et de recherche français ou étrangers, des laboratoires publics ou privés. 


\title{
Detour and break optimising distance, a new perspective on transport and urbanism
}

\author{
Alain L'Hostis \\ Université Paris-Est, Laboratoire Ville Mobilité Transport (LVMT), Institut Français des Sciences et \\ des Technologies des Transports de l'Aménagement et des Réseaux (Iftsttar) \\ 20 rue Elisée Reclus \\ 59666 Villeneuve d'Ascq \\ France \\ alain.lhostis@ifsttar.fr \\ + $33(0) 320429261$
}

\section{Introduction}

Distance, a central concept in geography, can also be seen as a key concept in urbanism and planning if we consider Offner's statement that the task of the planner or the urbanist consists in adjusting distances between functions (Offner, 2010). In the spirit of the definition of urbanism as establishing distances between urban functions, the distances of urbanism cover interventions on transport systems, actions on the spatial distribution of functions in urban and regional spaces, and joint action on both domains such as policies focusing on the transport-land use interaction (Webster et al., 1988). As Hall stated (1969), distance is at the heart of human, individual and social behaviour. But, if we consider the relatively short list of sources having focused on distances with a theoretical ambition (Brunet, 2009; Deutsch and Isard, 1961; Gatrell, 1983; Hall, 1969; Huriot et al., 1989), it has received less attention than we could expect for such a central concept, despite potential insightful implications for transport, urbanism and spatial planning. We propose here to establish a new perspective on transport and urbanism based on a renewed analysis of distance and of its properties.

This article develop two contributions on geographical distances. Geographical distance is a measurement of spacing between places and refers to the possibility to reach places. This relation to movement links geographical distances to routes in transport systems. The hypothesis that all geographical distances are optimal has been stated (L'Hostis, 2014, 2015). Distance influences the decision to realise or to avoid a trip, influences trip choices, influences all kinds of social interactions. For planners and urbanists, who have to solve issues with limited resources, this means that distance, as it conveys an idea of a search for optimality, can be used to take decisions. Furthermore, the analysis of triangle inequality, which is one of the four mathematical properties of distances or metrics, along with positivity, separability and symmetry, and whose role is to ensure the optimal character of distances, reveals key aspects of distances and of geographical spaces (L'Hostis, 2015). Assuming that distances differ from Euclidean straight line is considered as a necessary approach for urbanism and spatial planning (Cao and Zhang, 2013; Friedmann, 1993; Hillier, 2008).

We will now develop the idea that the optimum of distances is, rather counter-intuitively, supported by the existence of detours and breaks in trajectories and movements, and relies on the analysis of 
the three errors of interpretation of triangle inequality (L'Hostis, 2015). We will illustrate these three principles with concrete situations in the domains of urbanism, spatial planning and transport.

\section{First statement: distances carry an idea of optimality}

The first error of interpretation of the violations of triangle inequality consists in considering that distances can be represented by sub-optimal measurements, as in the example given by Haggett (2001: 248). This error resides in considering a sub-optimal measurement of space between locations as equivalent of a measurement of distance, despite its non-metric nature. Some authors see distance as a neutral concept, a geometrical abstraction not directly related to human behaviour. Conversely, we follow L'Hostis's demonstration (L'Hostis, 2014, 2015) that geographical distances are always optimal. In order to address this error of interpretation, we propose to state that distances contain the idea of optimum and that any distance is associated to a search for optimisation.

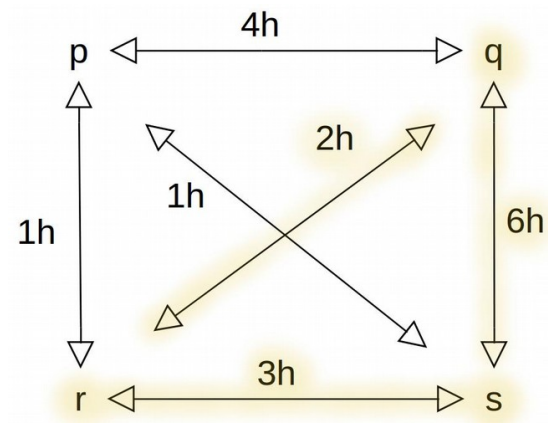

Figure 1: Four cities with nonoptimal separation measurements, violating triangle inequality (Haggett 2nก1 n 1

This first statement entails optimising routes of all kinds, and viewing them as supports of movement and hence as subject to an optimisation process.

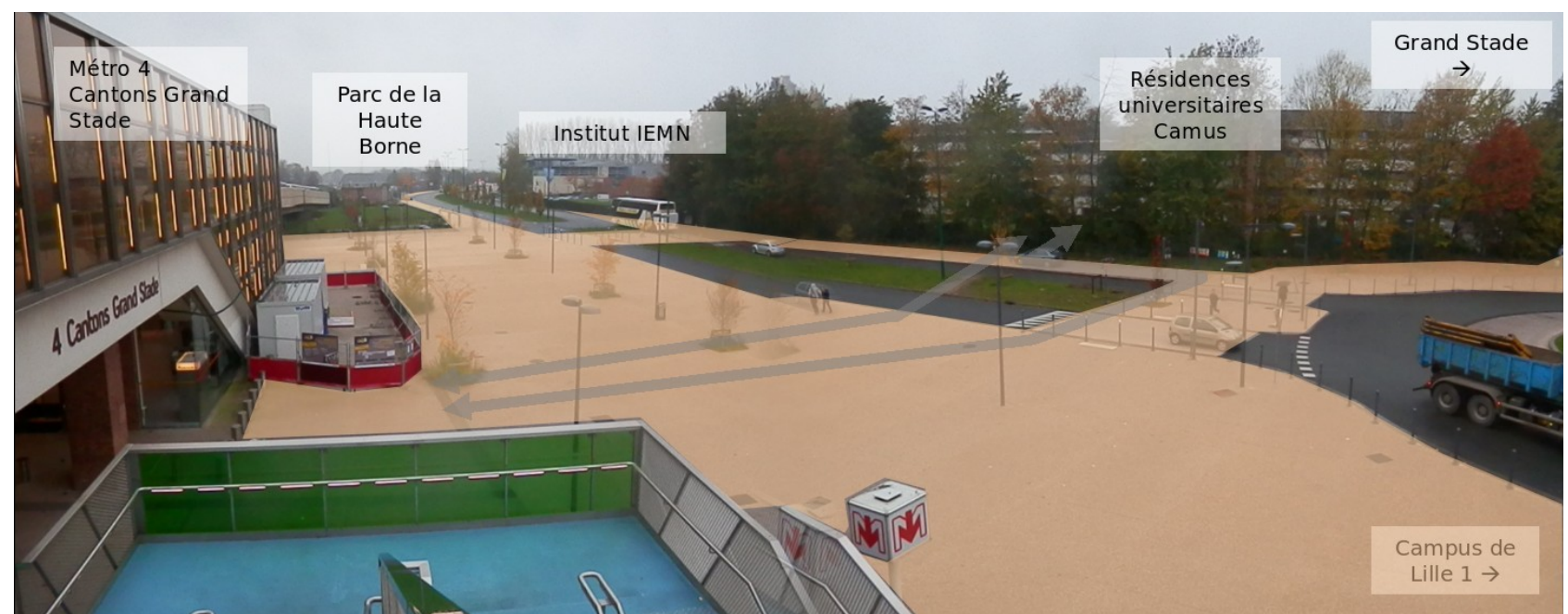

Figure 2: Spontaneous distances of the desire line, the strength of the search for optimum in the Quatre Cantons Grand Stade metro station surroundings (photo L'Hostis 2013)

An illustration of this principle can be read in the arbitrations realised in urban space design which has become a strategic issue for cities (Madanipour, 1999). We consider the case of the surroundings of the Quatre Cantons Grand Stade metro station in Villeneuve d'Ascq (FR) showing that not only planners create spaces but users also participate. A renewal of public space in 2012 adopted the design of this large open space in order to connect the metro station to the university campus, a new stadium and a technology park. 
The design opted for an open space to facilitate pedestrian mobility in access to the metro station. The design creates, favours, incites, curbs or lengthens distances; but the user also contributes to the design of space. University residences visible through the row of trees along Avenue Poincaré house numerous metro users. A door in the fence that allows for direct pedestrian access existed before 2012. Perpendicularly to this access, users maintain a desire line visible in the bare ground of the central reservation of Avenue

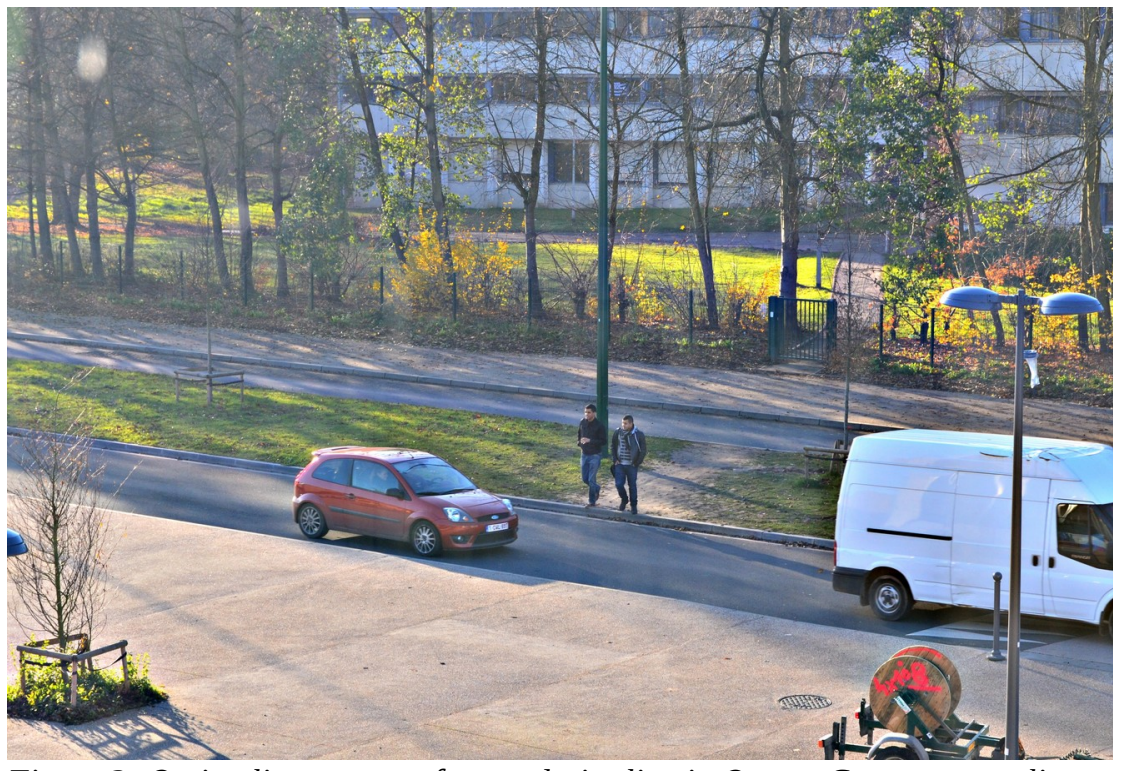

Figure 3: Optimality versus safety, a desire line in Quatre Cantons revealing the tension between least effort of users and road safety by designers (Photo D Bourbotte 2013)

Poincaré. Sociologists have introduced the term of desire line to describe the visible path generated by walkers in landscapes (Simmel, 1997: 171). These desire lines reveal the tensions in the formation of distances, most often resulting from a compromise between least effort and the risks associated with road safety (Moody and Melia, 2013).

A rather extreme choice was made in the design of the urban space of boulevard Montebello in Lille (FR): following several road traffic related casualties of pupils in Wazemmes high school on this very busy artery of Lille, thorn bushes in the middle and fences on the side were introduced to prevent straight line and least effort trajectories to the entrance of the high school.

\section{Spontaneous}

pedestrian distances shown by desire lines express the strength of straight line and of the search for optimum in the process of formation of distances. The 2012 project of the Quatre Cantons metro station has neglected this desire line that

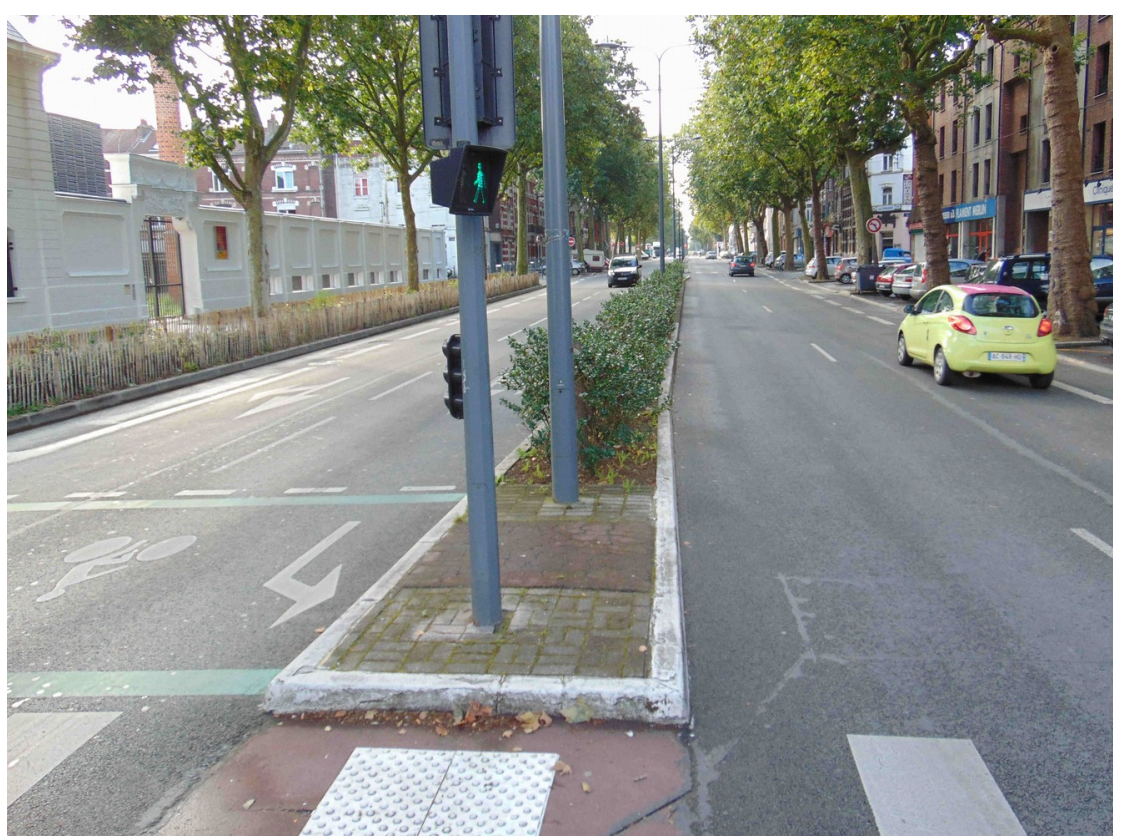

Figure 4: Thorn bushes in the middle and lateral fences on Montebello boulevard in Lille to prevent straight line pedestrian movements towards the entrance of Wazemmes secondary school (left) and channel them on safe pedestrian crossings, renunciation to the principles of legibility and openness of space design (Photo L'Hostis 2014)

existed before, privileging a safe crossing of the avenue on a large cross-walk close to the roundabout. Whether created by users or by design, both routes are shown in figure 2 and 3 . The first route is approaching the straight line, minimising physical effort, while the second promises, at 
the expense of a detour, a safer crossing of the road. The principle of optimality of distances expresses a recommendation to follow, or at least not to depart too much from, desire lines, figures of optimisation, and of solidification of social relationships (Simmel, 1997: 171). Optimality in the pedestrian routes design extends beyond the mere need to pass and to ensure safety. In Quatre Cantons, the designed pedestrian crossing favouring a safe intersection with automobile flow, at the expense of detour for pedestrians, represents a situation where the principle of optimality has not been fully applied. The choice made in favour of safety, and detrimental to optimality, has entailed the continuation of an unplanned practice of public space: the re-emergence of the desire line on the central reservation of Avenue Poincaré, away from the designed, safe pedestrian crossing, shows that the search for optimisation can prove stronger than the invitation to safety proposed by public space design. The objective of safety by design is challenged by practices, and the overall performance, if assessed, would probably be poor. A corrective intervention of the kind of those implemented on motorway-type axis in urban environment, or the one shown in Boulevard Montebello, would be a renunciation to the principles of legibility and openness of space design. These two examples express clearly the tensions in the design of public space with implications on pedestrian urban mobility, between an open, free and legible space and the principle of separation of flows (Buchanan, 1963) inherited from functionalistic urbanism (Dupuy, 1991). The principle of optimality of distance is expressed in the multi-criteria arbitration that opposes straight line to road safety concern.

The second illustration of distance optimality is provided by the analysis of public transport user maps. The layout of a transport network carries an intention of optimality when the user plans his trip. The promoters of the public transport network promise an efficient connection between places, and the user establishes his itinerary by mentally combining coloured lines and nodes that have become conventional for this kind of cartography. The famous London tube map proposed by Harry Beck in 1933 has been praised for its simplicity -its exceptional longevity proving its success- but has also been criticised for being misleading (Roberts et al., 2013; Scanlan, 2004: 394). The graphical harmonisation of inter-station distances introduces deformations of the topographic map by dilating the centre and compressing the periphery. This deformation gives the false impression that remote locations in the periphery are closer to the centre, and that central stations are further away than they are in topographic space. It is generally accepted that the misleading aspect of the Tube map has contributed to the success of the public transport system, especially among the users residing in the remote periphery (Sinnett et al., 2011). The process of harmonising inter-station graphical distances visually forces the optimal character of centre-periphery itineraries. But, at the same time, it induces the representation of suboptimal routes in the central area. It has become necessary to correct a part of the practices induced by the plan (Sinnett et al., 2011) by convincing passengers that between two metro stations located in close by areas, alternative transport modes, especially walking, can be more efficient.

The example of such an intervention is provided by the case of Portobello Road in west London. The project development of pedestrian route is financed by the transport authority Transport for London, and is aimed at replacing short trips by

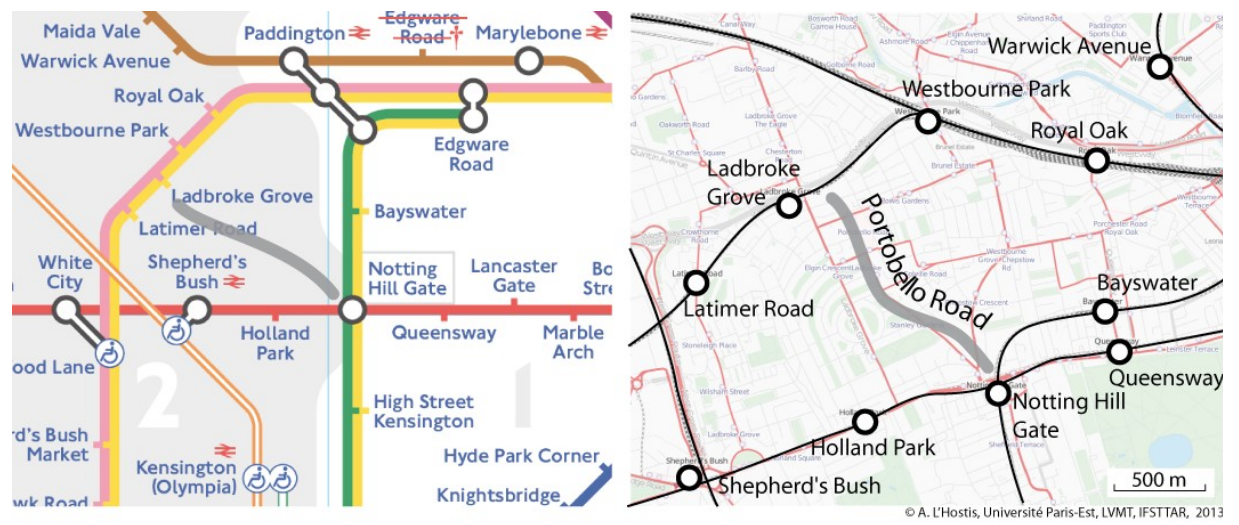

Figure 5: Developing a pedestrian link in London transport system in order to correct the misleading, sub-optimal distance induced by Beck's cartography (L'Hostis 2015) 
car and also by public transport (Sinnett et al., 2011). All public transport networks tend to be saturated in the densest parts of cities. Walking can replace short trips by public transport in the densest areas, providing travellers can consider using alternatives to public transport (Lavadinho, 20094). In Paris and London, most public transport users tend to believe that walking will never be as fast as public transport (Lavadinho, 2009). Nevertheless, when a metro delay reaches 15 minutes, the duration of pedestrian routes becomes competitive in the case of London; in Paris this time lapse allows walking the distance of three metro stations (Lavadinho, 2009: 5).

As the map induces sub-optimal routes, it also generates non-optimal practices (L'Hostis et al., 2009); by restricting possible choices it shows routes that are not distances because more efficient alternative itineraries exist. Correcting these sub-optimal behaviours supposes an action on street network design and on communication towards public transport users in order to indicate more efficient routes that avoid public transport.

The third illustration is found in works on transit oriented development (L'Hostis et al., 2009). Developing an urban form favouring the use of railway means, among other actions, increasing urban density around access points of the railway system. In this aim, the Bahn.ville 2 project in the SaintÉtienne (FR) urban region identified the need for a joint observation tool on transport and urban development

(L'Hostis et al., 2009). A central instrument of this observation tool consists in monitoring land and real estate

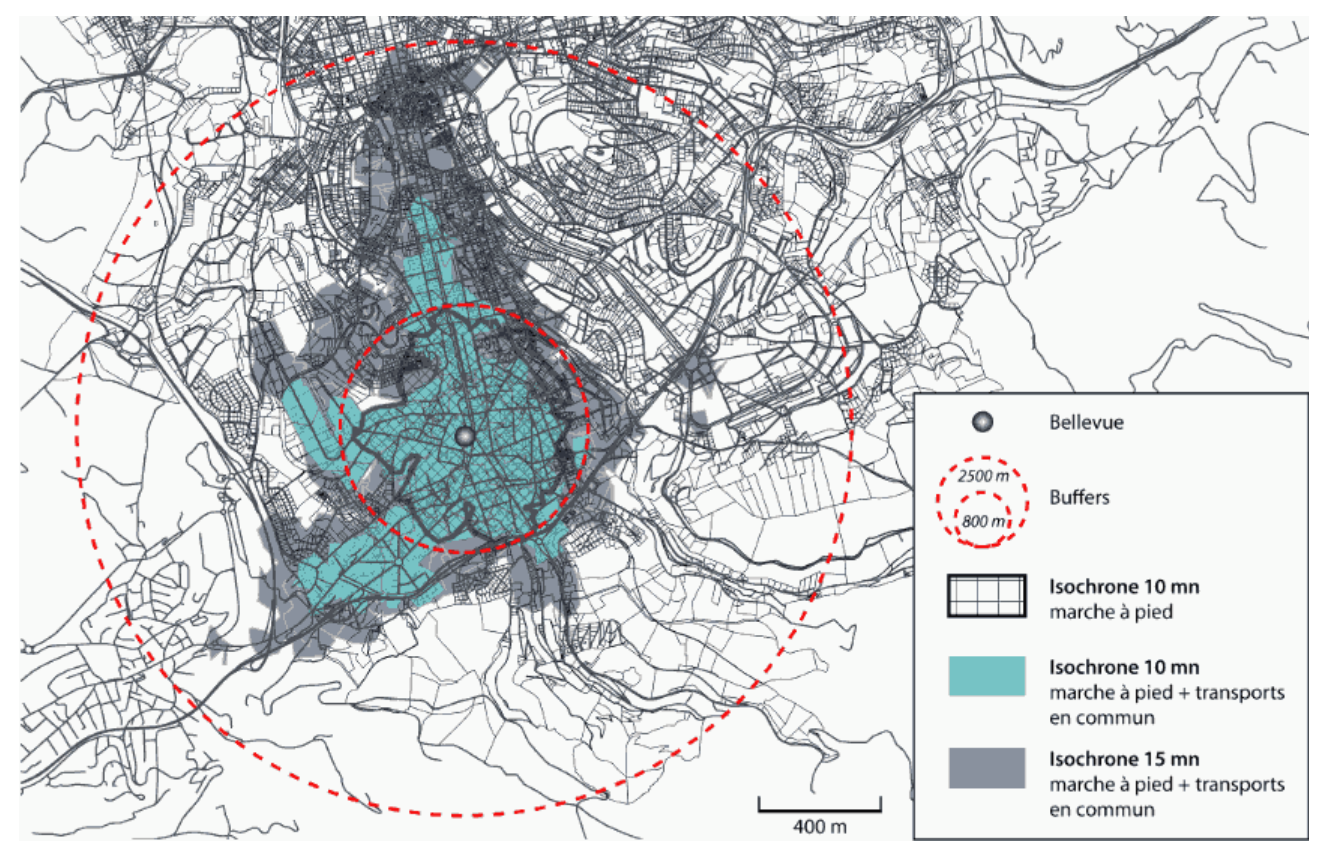
transactions

Figure 6: Land use monitoring for increasing density and improving pedestrian routes in the vicinity of railway stations (L'Hostis et al. 2009)

happening inside a

ten-minute walkable radius around railway stations (Bertolini and Spit, 1998).

In establishing the ten minutes walkable radii, we distinguish a theoretical measurement as the crow flies and an empirical measurement through the street network. The gap between these measurements indicates areas that could obtain a better access to the railway station providing the pathways were improved. The association of the issues of pathway improvement and of land monitoring for urban densification led the Saint-Étienne urbanism agency (EPURES) to extend the monitoring process to pieces of land that are too small to foster new buildings, but that could serve to improve public space and bike and pedestrian routes. As we see, the action on land is orientated towards an optimisation of pedestrian and bicycle distances which represents a strategic issue for railway station areas. This example shows that the issue of distance optimisation represents one possible levy in the implementation of an urban project. 


\section{Second statement: detours are most often due to an optimisation process}

The second error of interpretation of violation of triangle inequality, considering non-rectilinear routes as violation cases (Ahmed and Miller, 2007, page 4; Cauvin, 1984, page 62; Golledge, 1999, page 8; Müller, 1982, page 191; Perreur, 1989, page 133). It consists in a confusion between straight line and optimal route (L'Hostis, 2015). This error is associated to the issue of detour, to its status in transport and mobility systems. Is detour an anomaly that should be corrected each time it occurs? Some detours are indeed undesirable, but most of them correspond to a search for optimisation of distances of routes through transport networks. To deal with this error we propose to state that detour in distances is most often a means to optimise movement.

In the general frame of optimality, the idea of detours in distances raises a set of issues that urban planning and urban design has to take into account.

In the scientific literature on transport, detour is, in most cases, seen as a difficulty in moving, either a difficulty imposed by the network or an unnecessary difficulty. In a work on the urban street network and the fragmentation effect of infrastructure, Héran shows that a part of detour is unavoidable, due to the mere presence of buildings and, more generally, to the existence of spaces dedicated to functions other than mobility (Héran, 2009). For Héran an incompressible detour lengthens routes by an average 15 to $25 \%$. But another component of detour, due to the fragmentation effect of infrastructure and traffic, could be reduced, especially concerning active transport modes. In his analysis of urban distances, Héran distinguishes an average normal detour and a supplementary detour that could be reduced. When the street network is sufficiently meshed, detour remains limited. In this context detour is seen as a waste of energy, a loss of efficiency and a handicap for transport modes based on muscular strength. A similar analysis can be found in the literature in ethology (Schmidt et al., 1992). Detour gains a positive sense only in the domain of economics, with the famous roundaboutness that describes an investment devoted to a future increase in production. This figure of detour also possesses a positive sense in learning or narration processes; all these contexts are distinct from routing in geographical space. In our domain, detour is generally seen as a problem, an obstacle or a burden in the first place. If detour becomes positive, it turns into a paradoxical idea. 
The first illustration of the importance of detour in the optimality of distances, is the study of potential partners of the high-speed rail line project of the Îlede-France south bypass. This infrastructure project is totally included in the Île-de-France administrative region boundary; but five regions in western France have expressed interest in the project (Conseil Économique, Social et Environnemental des Pays de la Loire, 2010), and are potential funders, despite their location very far away from the infrastructure project. The fact that this equipment favours access to the high-speed rail lines of the north, east and south-east, from cities in western France explains the interest expressed by western administrative regions. This infrastructure will develop detours in distances by generating shorter time-distance optimum routes.

More generally, the extreme form of detour is space inversion identified by Tobler (1961: 106) and Bunge (1962: 172). As shown in figure 8 , space inversion describes the fact of starting a trip in a direction opposite to the final destination in order to access to a faster or more efficient transport mode. This phenomenon means that an intermodality

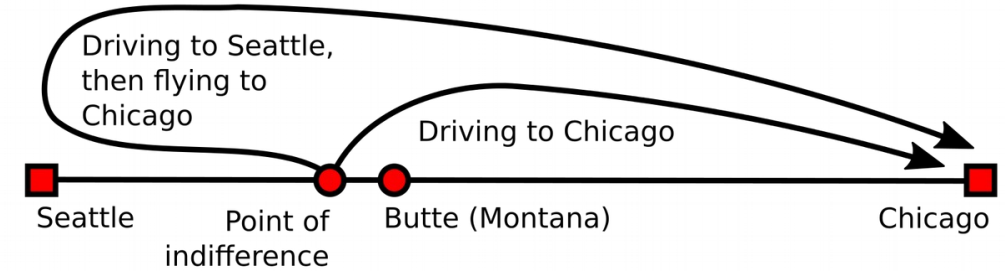

Figure 7: The priorities of transport infrastructure policy of Paysde-la-Loire region express an interest for the high-speed rail bypass south of Paris in Ille-de-France ("Contribution relative au projet de schéma national des infrastructures de transport du 9 juillet 2010 » 2010)

equipment -such as an airport- located far away will contribute to optimising distances from a given location. Usually, spatial planners and decision makers focusing on the accessibility of a given territory will tend to focus on local equipment, like airports, motorway entrances or railway stations, to improve the distances from and to external spaces. Conversely, space inversion shows a situation where equipment contributing to the external access can be located outside the territory it serves, and hence outside the space of intervention of the decision makers of this territory. 
In order to illustrate this case we consider three imaginary cities A, B and C during three historical periods before 1950, up to 1990, and beyond. From a situation where road and classic railway networks coexist, the development of high-speed transport leads to the introduction of the aerial mode and the motorway in the 1950s. The second phase of high-speed consists in the introduction of high-speed rail from the 1990s. During the first two phases, the shortest route from city $\mathrm{B}$ to city $\mathrm{C}$ by road, classic rail or motorway goes directly from $\mathrm{B}$ to $\mathrm{C}$. But in the last period, the fastest route is by high-speed rail to $\mathrm{A}$ followed by a flight to $\mathrm{C}$. The initial part of the route goes in the opposite direction, according to the space inversion principle. What are the facilities that contribute to the accessibility of the intermediate city? In the first two periods, only local connectivity to fast networks of road, classic rail and motorway, allows the production of direct fastest routes to $\mathrm{C}$. This supposes connections with motorway entrances and railway stations all located in the area where city B decision makers are legitimate to intervene. In the last period, accessibility of the intermediate city is provided by

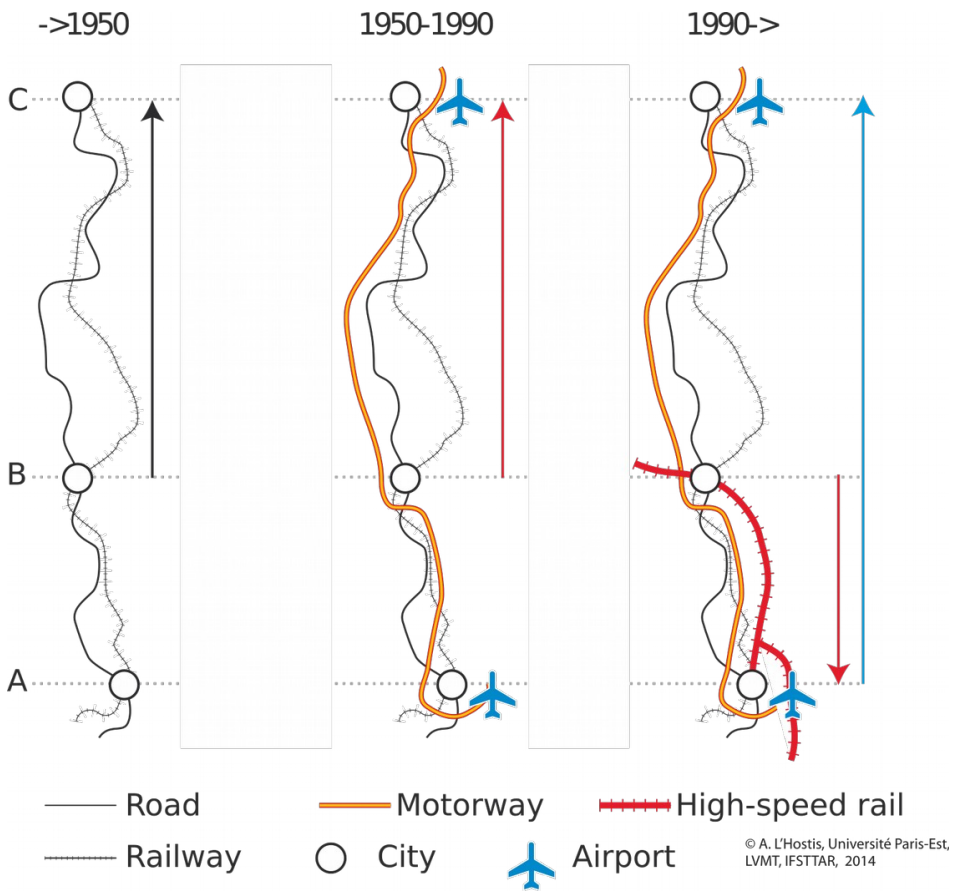

Figure 9: Introduction of spatial inversion, extreme form of detour, with the development of high speed in the trip from $B$ to $C$ connection to high-speed rail network, intermodal articulation of rail and air networks, and air transport supply in city A. In this case a remote facility located in city A, far from city B has become a strategic asset for the intermediate city despite being located out of its legitimate area of intervention. A relevant policy for developing accessibility of city B cannot rely on a development program of facilities located exclusively in its intervention perimeter.

As a second illustration of the role of detour in the organisation of distances, we consider a contribution on European accessibility (Lennert et al., 2010) based on contact potential indicators (Törnqvist, 1970, 1973). The possibility for daily commuting trips between cities is represented through all the available modal and intermodal chains. In the European context, intermodality plays an important role in long distance transport by combining air and high-speed rail. From the point of view of cities this intermodality sets up what can be called air-rail metropolitan systems (BozzaniFranc, 2006). These systems are based on a high-speed rail access to a major airport, according to a configuration met by 6 cases in Europe, with two main cases around Frankfurt and the axis LilleParis-Charles-de-Gaulle (L’Hostis et al., 2015). 
Air-rail intermodality generates many detours and space inversion processes. Figure 10 reveals the space inversion by confronting the straight line linking origin and destination, to railway axes leading to airports used in the actual route. These spatial inversions are all the more remarkable since they rely on a terrestrial part of routes.

Space inversion as the extreme form of detour,

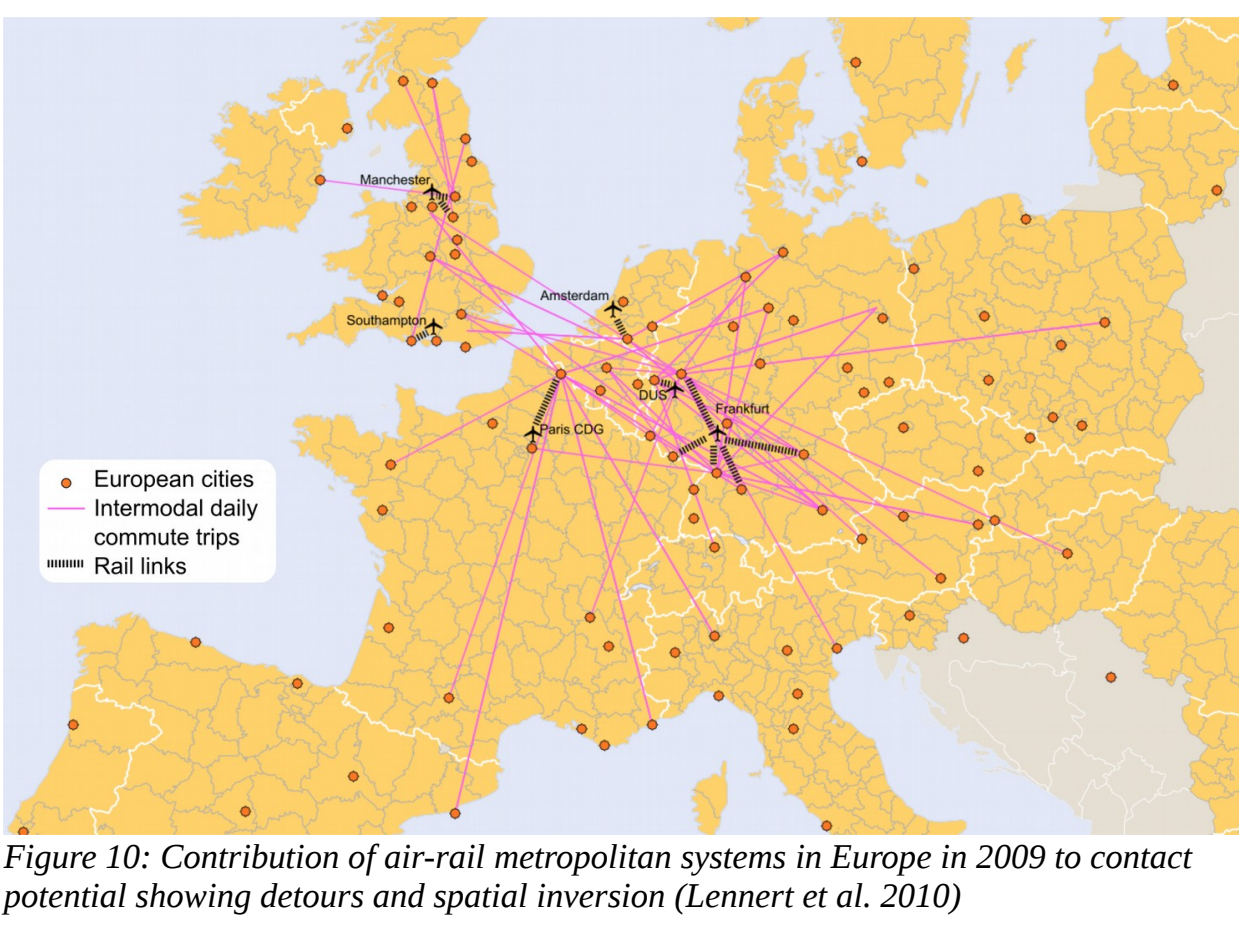
has to be considered in potential showing detours and spatial inversion (Lennert et al. 2010)

spatial planning. Paris-Charles-de-Gaulle airport is an entry point to the world for Lille and the Nord-Pas-de-Calais region (Bozzani, 2005; Menerault and Stransky, 1999); space inversion occurs when the traveller takes a train towards the south in order to reach European destinations located north of Lille. How can local decision makers assume this space inversion that involves getting rid of a rationale of local airport facility development policy and privileging an approach based on transport service? This is the issue raised by space inversion, the extreme form of detour, in the case of Lille.

The third illustration of the importance of detour in the formation of distances is provided by public transport network cartography designed for users. These maps can be categorised according to two modes of representation: most of them adopt a deformed geometrical ${ }^{1}$ representation principle, while others use a topographic mode, based on conventional cartographic location of places. In the first case, which corresponds to Harry Beck’s classic London Tube map (Roberts et al., 2013), rectilinear segments remove the local detours of transport lines. In these representations, detours of lines are erased, but another category of detours associated to connections between lines is highlighted.

Any user of public transport systems is highly likely to experience a change of vehicle or a change of modes during her/his trip. In the Paris agglomeration, we estimate that about half public transport trips use several lines or transport systems (Massot, 1999). This proportion can reach $70 \%$ in agglomerations like Lyons (Richer et al., 2012).

1 In this context, many authors in geography use the adjective topological to refer to the network layout.

Nevertheless, topology is used in the field of anamorphic cartography to deal with transformations of space such as contraction, dilatation and tear. In an objective of clarification, I consider that topology should be confined to this set of issues and not used when simply referring to network layout. 
The Lyons network layout is marked by the will to avoid the creation of a single focal point of heavy lines. Consequently, the share of routes involving several lines is structurally higher than in other equivalent agglomerations. For instance, the route between the two main railway stations, Perrache and Part-Dieu is not possible by metro without changing lines ${ }^{2}$. The design of the simplified user map of which the central section is reproduced in figure 11 follows the principles introduced by Harry Beck for London: lines are turned into rectilinear segments aligned on the

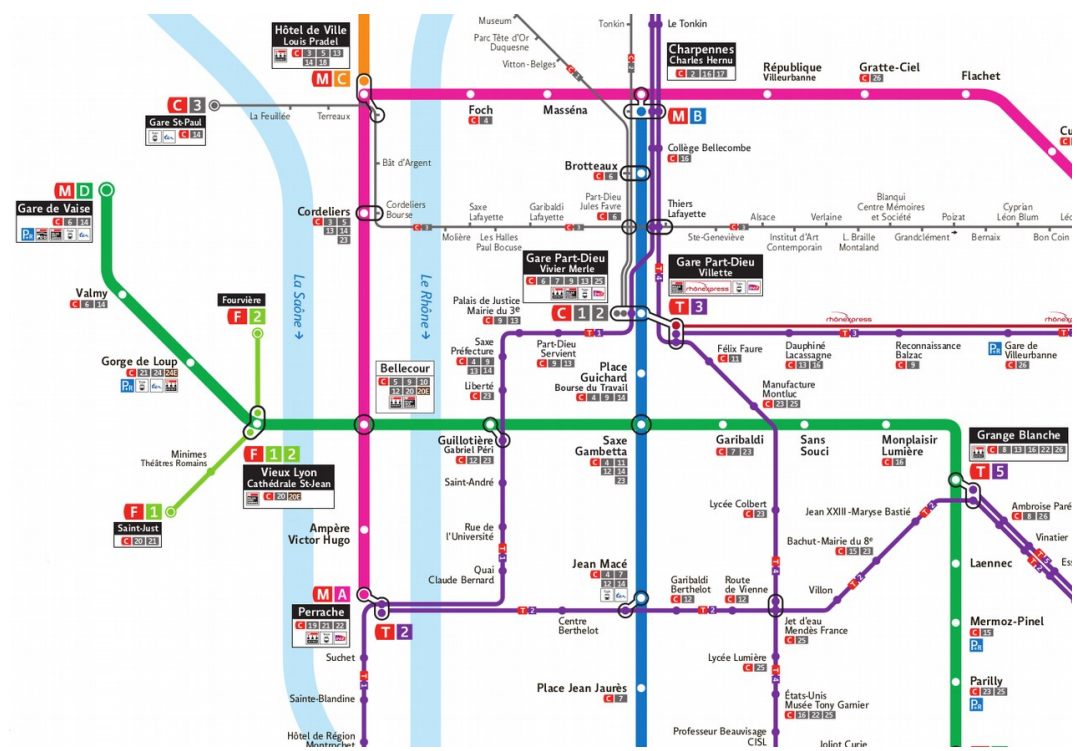

Figure 11: Central sector of Lyons public transport network, a necessary intermodality (source http://www.tcl.fr browsed in 2014) eight possible directions of the octolinearity principle. The representation graphically highlights rectilinear itineraries and connection stations. As routes in public transport network depend on the initial design choices of the system, the map expresses a pedagogy of detour, in order to show how to establish distances that are optimal and that assume changing between public transport lines.

Any transport system user has, deep down inside, an intimate reference to the straight line. The representations that are provided to him take this idea into account by erasing detours on the lines as in Harry Beck's London tube map, or, conversely, by elaborating a pedagogy of detour that underlines exchange poles that create spatial and temporal detours.

Detour turns into a positive value, as a means to optimise a route. Fast infrastructures tend to increase the length of detours and contribute to congestion, as Héran shows (2009), but this results from an optimisation process by individuals. The etymology of the word detour carries this ambiguity by meaning the tortuousness of routes, and also the fact of getting away from a direct route and reaching a given place. Optimality of distances highlights the search for an optimal route, as sinuous as it may be; in this sense we can state that detour is most often a search for optimisation.

\section{Third statement: breaks participate in optimising distances}

Considering a break in an itinerary as a violation of triangle inequality and a cause of sub-optimality of distances (Huriot et al., 1989: 313) is a third error of interpretation of this metric property (L'Hostis, 2015). Following the views of Brunet, a break represents a reloading of the energy necessary for movement (Brunet, 2009: 16). Consequently, break contributes to the optimality of routes, and hence to the optimality of distances. To address this error of interpretation we state that breaks in movement contribute to optimising distances.

2 This issue has been tackled with the introduction of the first tramway line of the Lyons network in 2001, connecting the two stations directly. 
A break is often seen as a factor of sub-optimality in movement. The waiting time before boarding a public transport vehicle is considered as a waste of time for travellers. Nevertheless, any movement in space needs energy loading and reloading, breaks, that are not sources of sub-optimality, but rather contribute to the realisation of optimal routes for persons or objects on the move. Break is necessary in order to provide the momentum for movement. Displacement is not a continuous movement. It contains breaks. The first set of illustrations of this principle is the reflection on urban design for pedestrians, i.e. public space design, that highlights the idea of breaks (Lavadinho, 2011: 145). The objective is to favour an appropriation of space by pedestrians through what Lavadinho

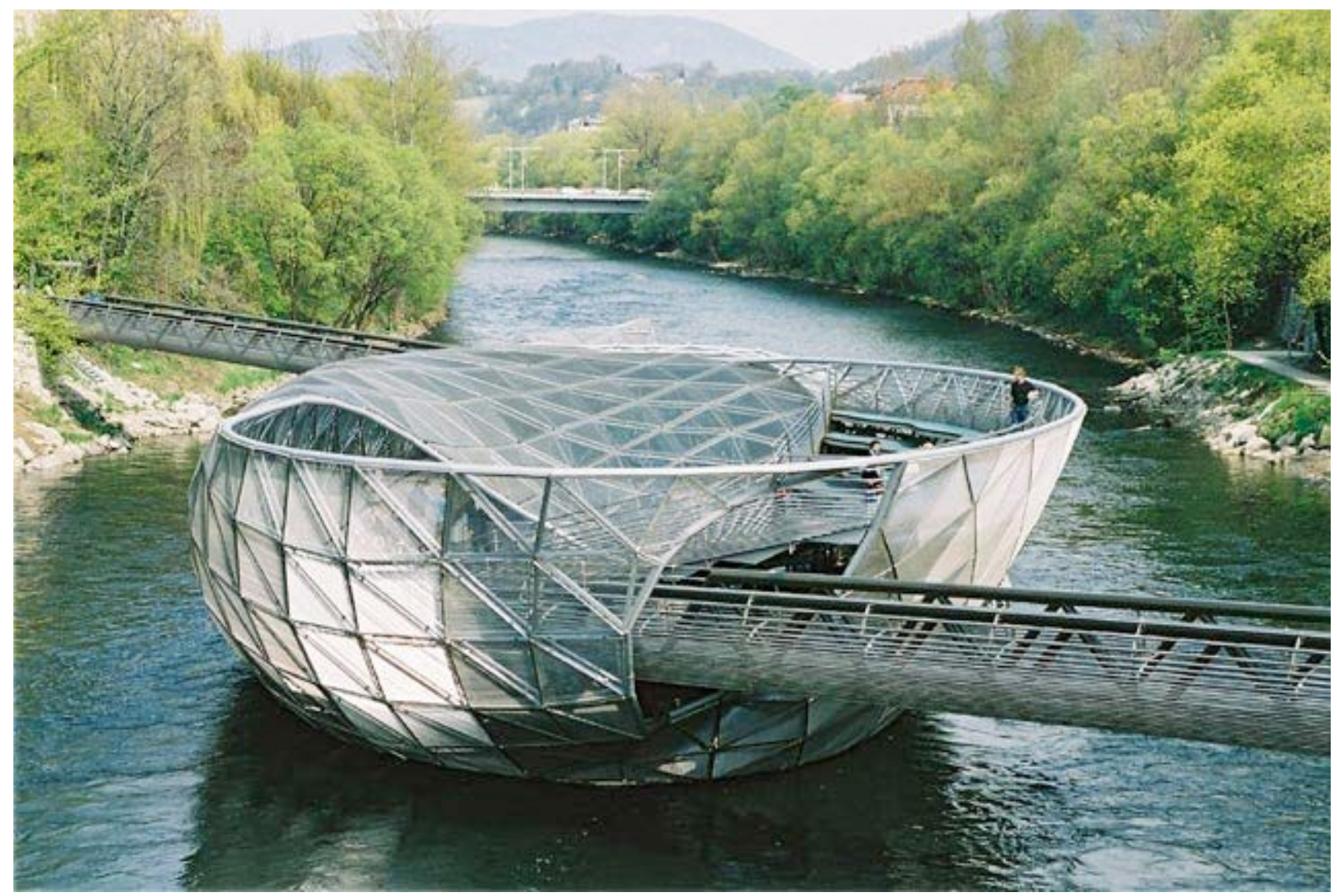

Figure 12: Footbridge and island on river Mur in Graz (AU), a break for favouring pedestrian mobility ("The Island in the Mur" 2014)

calls a lateralisation (2011, page 201), i.e. the possibility to exit one's route for a break, a breathing space, which will provide the momentum necessary to complete one's pedestrian route.

The bridge on river Mur in Graz (AU) materialises the break in a pedestrian itinerary in the form of a two-section footbridge linked through a central island that floats in the middle of the river (The Island in the Mur, 2014). Taking advantage of a detour, the pedestrian has the possibility to physically stop in the café located on the island, but the break can also be simply mental: the route possesses this breathing space, this passage, this instant, that provides rhythm to the crossing and the itinerary considered in a wider scope. The island halfway through the bridge is a break, providing it can be appropriated as such by the walker. The appropriation process relies on a symbolic dimension that allows for an interaction between the subject and his environment, according to a mechanism that Gibson has theorised with the concept of affordance (Gibson, 1977; Turner and Penn, 2002). We can remark that in the case of the island on river Mur, detour and break are superimposed: the straight line of the footbridge is interrupted by the crossing of the island, and the island fosters the facilities allowing break. With this bridge, a break is proposed, but a detour is imposed. 
For Lavadinho, the facilities of break allowing lateralisation during the trip, providing they are placed carefully, can contribute to the implementation of agglomeration-wide pedestrian networks. The rationale of the spatial configuration of these facilities can be compared to the distribution of caravanserais, service-stations, hotels and other places dedicated to loading the energy necessary for movement. It is a matter of optimisation. These facilities of the rest of pedestrians cover a wide variety of types, with, for instance, a free and open space with benches, around the viewpoint provided by a belvedere, an overhang; they can also involve playgrounds in a gamification of urban space (Lavadinho, 2011: 189). As shown in figure 13, the urban space design of the surroundings of the Vincennes regional railway station in Paris (FR) follows these ideas with seats located so that they provide a view of urban perspectives for passers-by, and urban playground with artificial fog. In figure 14, the gamification principle is exemplified in Saint-Gall's Stadtlounge (CH). Passers-by are invited to sit and rest on a couch, as they would do at home or in a café. As Bailly states, the representation of his route by a pedestrian is organised around a series of points, of landmarks, which are essentially symbolic (Bailly, 1990: 268).

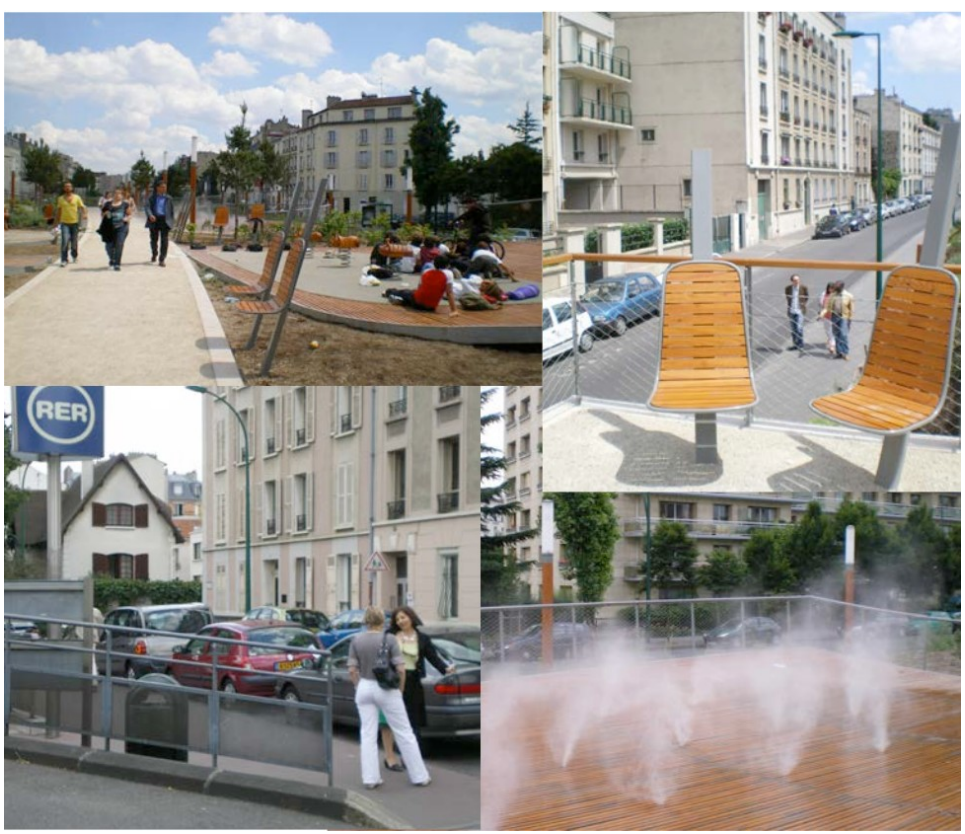

Figure 14: Facilities of break in pedestrian itineraries leading to the Vincennes regional railway station (Lavadinho 2011)

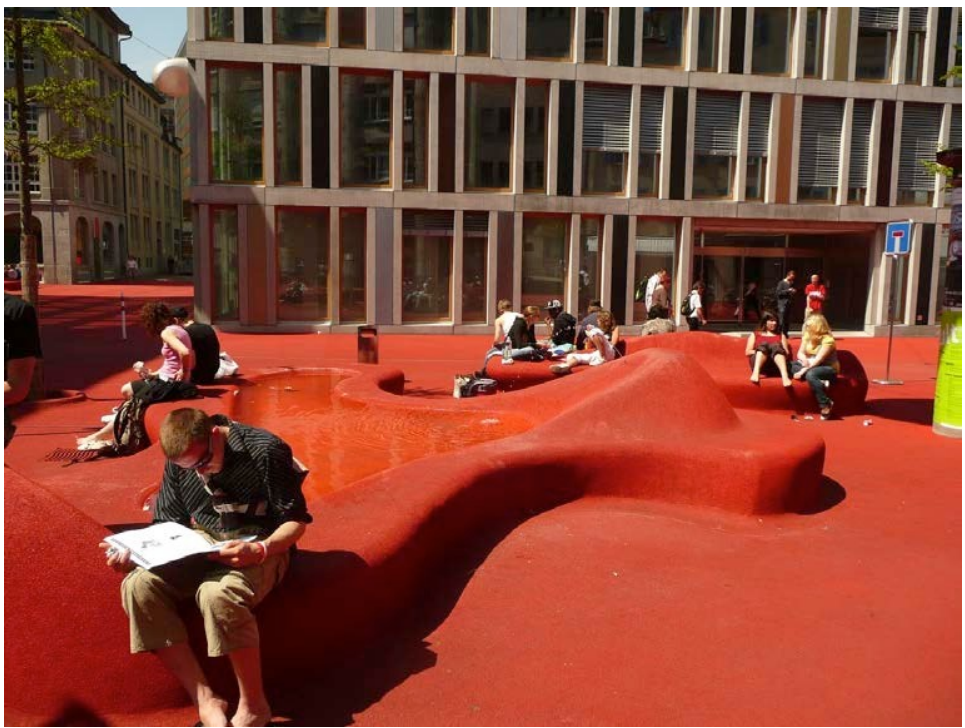

Figure 13: Stadtlounge, an urban installation in Saint-Gall (Switzerland) allows for lateralisation of pedestrians (Lavadinho 2011 280 ) 
Break can be symbolic, but can also be spiritual. The crosses are omnipresent in landscapes of rural communes in Brittany (FR) (Castel, 1980). Always facing west, they bear the name of a place or a saint, and are most often located at a crossroads, and almost always on a roadside. The crosses, as landmarks, provide a sense, a meaning to the way and to the journey. Travellers establish their optimal route by using these landmarks. A villager will use the marking of crosses to indicate a route to a traveller. In addition, the routes of pilgrims are punctuated with these singular points that provide direction, and reassure the traveller afraid of getting lost. Nevertheless, beyond its utilitarian function, the cross also has a spiritual dimension. The pilgrim's route, full of risks, "requires divine protection” (Le Scouëzec and Masson, 1982). The cross provide "support from divine force" through a spiritual break. The pilgrim needs this equipment that allow him to follow the route without getting lost, in all the senses of the expression (Lefébure, 2004, page 60).

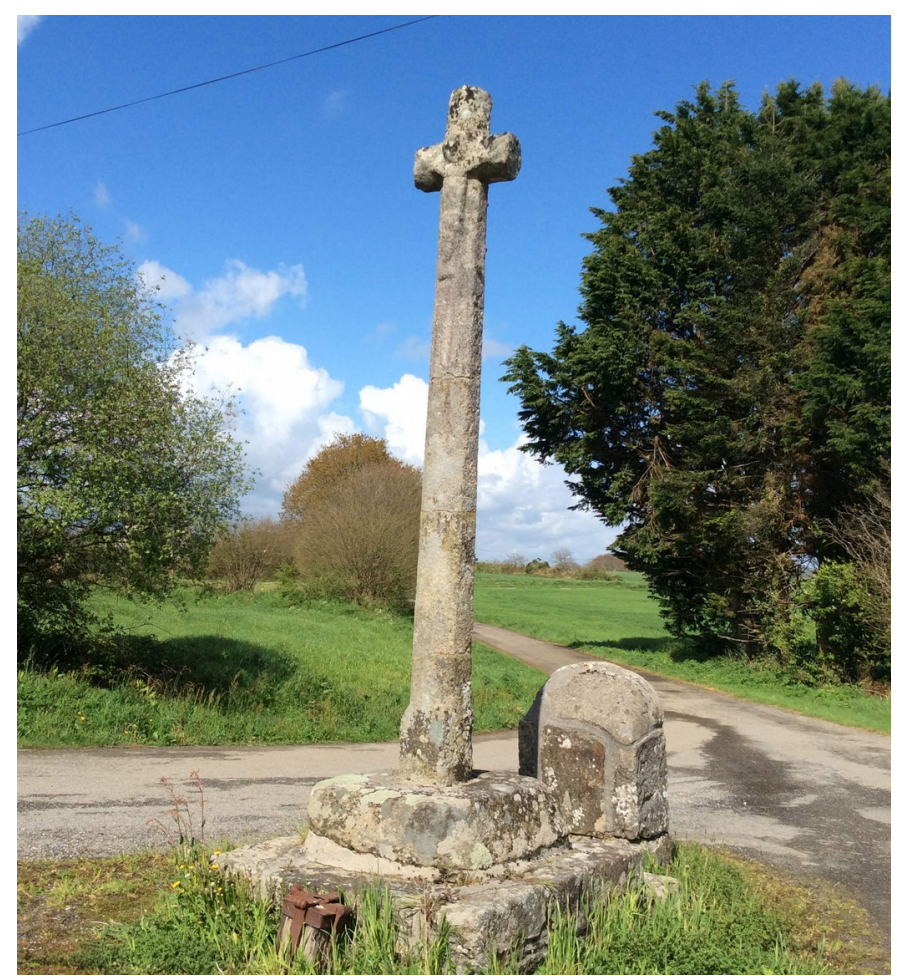

Figure 15: Le Keff cross in Saint-Thegonnec, Finistère (FR) landmark for travellers and facility of a spiritual break (photo Annie L'Hostis 2014)

If we extend the reflection, we see in this urban function of break the possibility for an aesthetic appropriation of space, in the sense of an artistic experience. Crosses as art-work, but also the location of seating allowing for enjoyment of the urban landscape around the railway, constitute invitations to an aesthetic experience in urban space. This analysis suggests a possible function for pieces of art inserted in public space. Pedestrians in Mamfe in Cameroon can use the numerous statues installed in the public space for this break function. Art can contribute to providing break in pedestrian mobility networks.

The facilities of break represent an urban paradox: they organise the possibility of a break, of a waste of time in a trip, and they also contribute to optimising pedestrian distances in a wider network. In that sense break should be considered as a relevant principle for the design of urban space in order to support a pedestrian oriented urban form.

The second illustration of the role of break in establishing distances is provided by the analysis of railway stations as nodes and places (Bertolini and Spit, 1998). Railway stations have become key objects in the organisation of transport system

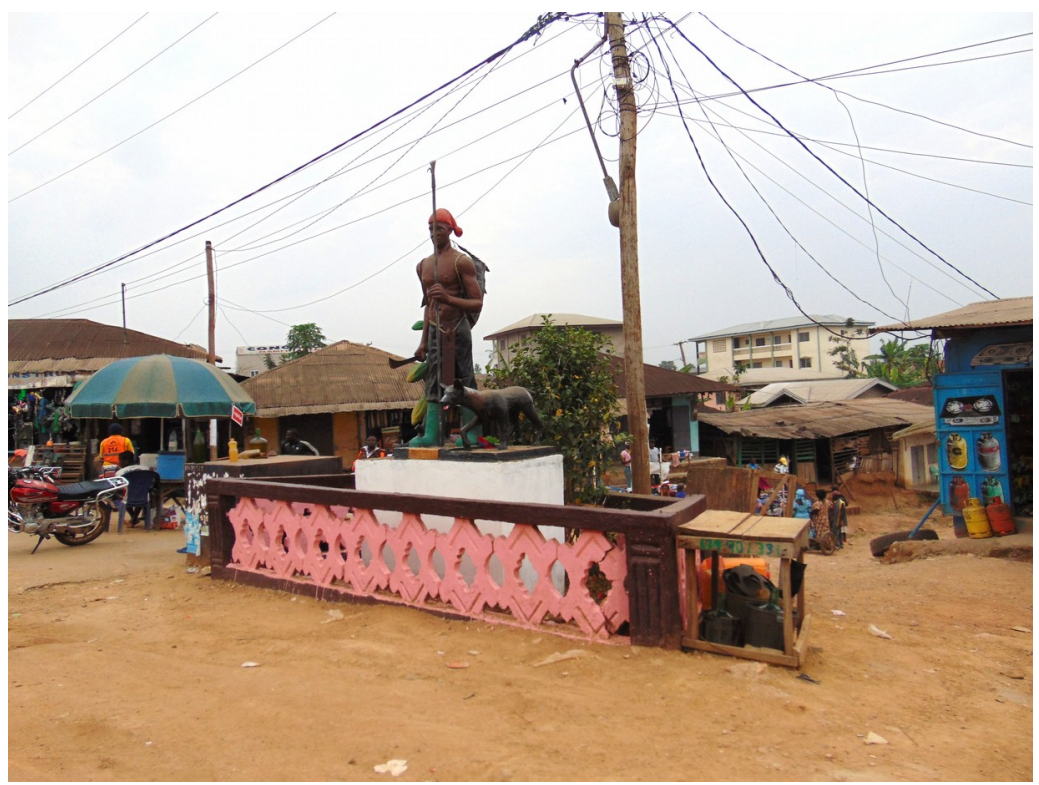

Figure 16: Statue of a cacao farmer in Mamfe (CM), landmark and alternative to cars. We have possibility of break for pedestrian mobility (photo L'Hostis 2015) 
investigated the perception and representation of railway stations by users. As an illustration, Charlotte, who we asked to draw the railway station space, proposed a representation with the major elements of entrance, ticket offices and platforms. Between the functional entrances and exits of the railway station space, the representation shows the facilities of break available to travellers.

These railway stations are also, as urban places, spaces where service and retail functions develops. The viability of their economic model depends on it. Services to individuals, and particularly food retail, occupy a prominent place among these functions. Recent research show the evolution of food and drinks packages in adaptation to urban lifestyles, made of mobility and immobility, both desired or constrained (Monreal et al.). These evolutions provide an even stronger importance to the urban facilities of break. And reflections on the design of the $\mathrm{La}$ Défense (FR) shopping mall near Paris highlighted the idea of break with a principle of pacing routes, providing the various groups of users with necessary places and facilities for break: rest points, kid's corners, snack breaks (Boumoud, 2012: 183; Roty, 2000). Ambiguity is not absent from this last avatar of urban break: commoditisation of urban space (Cronin, 2006) and favouring food regimes with adverse health effects (Marmonier, 1999) can be criticised. Assessing these facilities of pedestrian break from the point of view of public health involves considering a complex set of issues. Reflections on shopping mall design can join

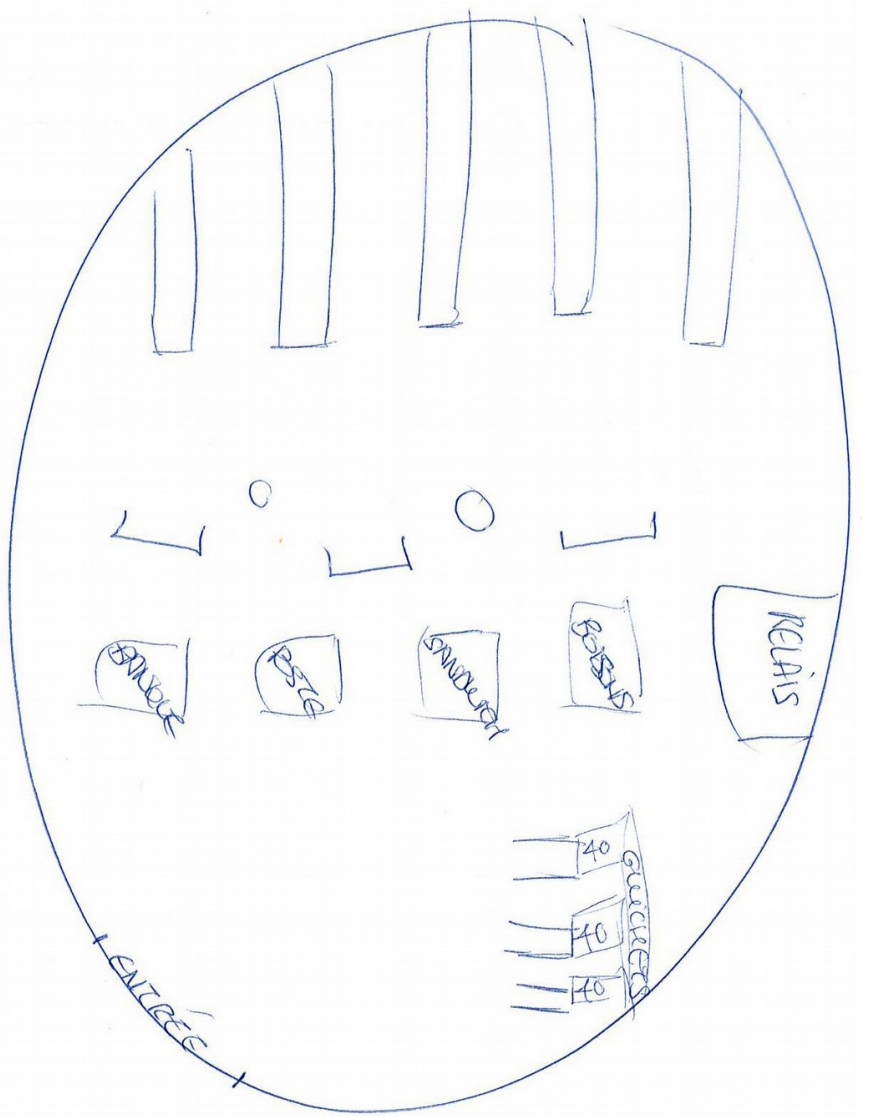

Figure 17: Charlotte's mental representation of St-Lazare in Paris (FR), break as an opportunity inside an optimised route this problematic through the concept of pedestrian station (Amar et al., 2007). More broadly, defining the basket of services and retail of the railway stations is a true urban issue that should be considered together with the surrounding urban area supply (L’Hostis et al., 2009).

Railway stations are urban places, but also transport nodes. This is the place where we come to take -and wait for- trains. We get to the railway station to establish a distance, i.e. an optimised route, and yet we come down and wait. The paradox of breaks in routes is here manifest. The dwelling time in the railway stations develops inside a long distance journey, but provides, through lateralisation, the possibility to carry out an activity in the station or in the surroundings. In the time-space paradigm (Chardonnel, 2001; Hägerstrand, 1970), a tiny time-space prism opens up for the traveller waiting for his train. Once he is aware of the time at the railway station and the actual departure time of his train ${ }^{3}$, the potential for a new trip contained in a larger optimised trip opens up. In the case of railway stations, as we see, the reflection on the break that optimises the route, allows us to consider railway stations as spaces for lateralisation, of opening of time-space for an activity that develops inside a larger itinerary without altering it. As Amar states in his analysis of the La Défense exchange pole, "the path step, even forced, is enriched with opportunities" (Amar, 1996).

3 The importance of time in cities and in railway stations is highlighted by Lallier in his documentary film on railway and metropolises (Lallier, 2011). 
This reflection on break echoes the issues of in-place economy (Davezies, 2009; Terrier, 2006) that, rather than analysing household income at home-place, consists in studying the location of income spending, the spatialisation of which can take a very distinct pattern. The free time of passengers waiting for their train is an opportunity to capture locally an income earned elsewhere.

Beyond the issue of railway stations, in a general context of increasing porosity between professional travel and tourism (Kellerman, 2012), this reflection entails considering the facilities of tourist break -hotels and restaurants- as elements of attractiveness for professional mobility and not only for tourism. The fact that reloading and break obey organisational constraints of transport and mobility implies that a territorial development aiming at taking advantage of the reloading function should rely on a deep understanding of the functioning of transport systems. Such is the case of the tourist development with relays and restaurants on the N6 road in Burgundy (FR) as path step for Parisian drivers to the Mediterranean coast (Bavoux, 2009). More broadly, the idea of break is widely observed in tourist issues if we consider that, most often, the spatial pattern of tourist mobility that consists in a series of path steps to enjoy a view-point, a piece of art or a particular atmosphere; from that perspective, the break, as much as the path, reveals the engagement of the tourist.

Etymology echoes our analysis of mobility: the break refers to the fact of interrupting an activity, and refers also to the time spent on this interruption. The break interrupts and provides rest. Its negative side, the interruption of an effort requiring activity, is justified by the benefits it provides: the rest gives back the strength to return to the route.

\section{Conclusion}

From a discussion about the mathematical properties of metrics, we identify three fundamental characteristics of distance, which are optimality, detour and break. We then explore the implications of these properties for transport planning, urbanism and spatial planning.

We state that distances contain the idea of optimum and that any distance is associated to a search for optimisation. We illustrate this idea by analysing pedestrian movement in cities and route choices by means of public transport maps. Spontaneous pedestrian distances shown by desire lines express the strength of straight line and of the search for optimum in the process of formation of distances. This discussion reveals the tensions in the design of public space with implications on pedestrian urban mobility, between an open, free and legible space and the principle of separation of flows inherited from functionalistic urbanism, and supported by concern for road safety. The principle of optimality of distance is expressed in the multi-criteria arbitration that opposes straight line to road safety concern.

Optimality is introduced by design in public transport maps. But the design principles of a simplified graphic can infer sub-optimal routes that, as in the case of London metro, have to be corrected in order to relieve the overloaded central parts of the network. Because distance carries the idea of optimum, even if not unequivocal, it is relevant as an operational concept that has to deal with limited resources.

The second principle we state is that detour in distances is most often a means to optimise movement. The presence and network layout of fast transport systems generates most of the detour observed in geographical spaces at regional scale. This raises the issue of local policies dedicated to accessibility improvement, because the extreme form of detour, space inversion, shows a situation where equipment contributing to the external access can be located outside the territory it serves, and hence outside the space of intervention of the decision makers of this territory. Detour has to be taken into account in regional transport policies.

Detour also exists in urban spaces as in the case of public transport networks. As public transport 
operations favour an organisation in lines, a given trip is most likely to have to change lines. This is why public transport maps have to develop a pedagogy of detour my means of graphic design highlighting intermodality and exchange poles. Optimality of distances highlights the search for an optimal route, as sinuous as it may be; in this sense we can state that detour is most often a search for optimisation.

The third statement is that breaks in movement contribute to optimising distances. In order to develop agglomeration-wide pedestrian networks it is necessary to introduce the possibility of break in urban space that allows for long distance pedestrian routes. Break for pedestrian mostly provides energy for reloading movement, but can also be symbolic, spiritual or aesthetic. Railway stations represent another facility of urban break. Users get to the railway station to establish a distance, i.e. an optimised route, and yet they come down and wait. The facilities of break represent an urban paradox: they organise the possibility of a break, of a waste of time in a trip, and they also contribute to optimising distances in a wider network. In that sense break should be considered as a relevant principle for the design of urban space in order to support a pedestrian oriented urban form.

This reflection on geographical distances has proven fruitful in the domains of transport, urbanism and spatial planning. Starting from mathematical properties of distances we come to discuss the orientations of urban space design between openness and separation of flows, the distribution of services in the urban form in the aim of establishing efficient pedestrian networks, or the design of urban or regional transport systems that assumes detours.

\section{Bibliography}

Ahmed N, Miller H J, 2007, “Time-space transformations of geographic space for exploring, analyzing and visualizing transportation systems” Journal of Transport Geography 15(1) 217

Amar G, 1996, “Complexes d'échanges urbains, du concept au projet, le cas de la Défense” Les Annales de la recherche urbaine (71) 93-100

Amar G, Michaud V, Bellec Y, Segrestin B, 2007 Le Piéton considérable, la marche au coeur des mobilité, 1ére phase du séminaire: le partage de connaissances (RATP, Paris)

Bailly A, 1990, “Les Représentations de la distance et de l'espace: mythes et constructions mentales” RERU (2) 265-270

Bavoux J-J, 2009, “Structuration du territoire bourguignon : de l'île à l'isthme” Revue Géographique de l'Est 46(1-2), http://rge.revues.org/1195\#tocto2n7

Bertolini L, Spit T, 1998 Cities on rails: the redevelopment of railway station areas (E \& FN Spon, London)

Boumoud A, 2012 La grande gare contemporaine et le labyrinthe du transport multimodal: vers une nouvelle approche de la lisibilité, l'exemple de la gare de la Part-Dieu à Lyon, Université de Grenoble, http://tel.archives-ouvertes.fr/tel-00956736/

Bozzani-Franc S, 2006 Grandes Vitesses, Métropolisation et Organisation des territoires : L'apport de l'intermodalité aéro-ferroviaire à grande vitesse au rayonnement métropolitain, Université des Sciences et Technologie de Lille - Lille I, http://tel.archives-ouvertes.fr/tel00294581

Bozzani S, 2005, “L’Intermodalité air-fer à grande vitesse au service du rayonnement métropolitain: 
étude de l'articulation modale à l'aéroport de Roissy-Ch. de Gaulle au départ de Lille” Cahiers Scientifiques du Transport 47 61-88

Brunet R, 2009, “Les sens de la distance” Atala 12 13-32

Buchanan C, 1963, “Traffic in towns”, http://rid.trb.org/view.aspx?id=131511

Bunge W, 1962 Theoretical geography seconde éd. augmentée 1966 (Gleerup, Lund)

Cao K, Zhang Y, 2013, “Urban planning in generalized non-Euclidean space” Planning Theory 12(4) 335-350

Castel Y-P, 1980 Atlas des croix et calvaires du Finistère (Société Archéologique du Finistère, Quimper)

Cauvin C, 1984 Espaces cognitifs et transformations cartographiques

Chardonnel S, 2001, “La Time-geography: les individus dans le temps et l'espace”, in Modèles en analyse spatiale Traité Information Géographique et Aménagement du Territoire, Série aspects fondamentaux de l'analyse spatiale (Lavoisier, Paris), pp 129-156

Conseil Économique, Social et Environnemental des Pays de la Loire, 2010, “Contribution relative au projet de schéma national des infrastructures de transport du 9 juillet 2010”, Conseil Économique, Social et Environnemental des Pays de la Loire, Nantes, http://ceser.paysdelaloire.fr/images/stories/etudes-publications/transport/2010-11-19_SNITvalide.pdf

Cronin A M, 2006, “Advertising and the metabolism of the city: urban space, commodity rhythms” Environment and Planning D: Society and Space 24(4) 615-632

Davezies L, 2009, “L’économie locale «résidentielle»” Géographie, économie, société 11(1) 47-53

Deutsch K W, Isard W, 1961, “A note on a generalized concept of effective distance” Behavioral Science 6(4) 308-311

Dupuy G, 1991 L’Urbanisme des réseaux (Armand Colin, Paris)

Friedmann J, 1993, “Toward a non-Euclidian mode of planning” Journal of the American Planning Association 59(4) 482

Gatrell A C, 1983 Distance and space: a geographical perspective (Clarendon Press Oxford), http://www.getcited.org/pub/102287206

Gibson J J, 1977, “The concept of affordances” Perceiving, acting, and knowing 67-82

Golledge R G, 1999 Wayfinding Behavior: Cognitive Mapping and Other Spatial Processes (JHU Press)

Hägerstrand T, 1970, “What about people in regional science?” Papers of the Regional Science Association 24 7-21

Haggett P, 2001 Geography, a global synthesis (Prentice Hall, Harlow) 
Hall E T, 1969 The Hidden Dimension Anchor Books (New York)

Héran F, 2009, “Des distances à vol d’oiseau aux distances réelles ou de l'origine des détours” Flux $\mathbf{n}^{\circ}$ 76-77(2) 110-121

Hillier J, 2008, “Plan(e) Speaking: a Multiplanar Theory of Spatial Planning” Planning Theory 7(1) 24-50

Huriot J-M, Smith T E, Thisse J F, 1989, "Minimum-Cost Distances in Spatial Analysis” Geographical Analysis 21(4) 294-315

Kellerman A, 2012 Daily Spatial Mobilities: Physical and Virtual (Ashgate Publishing Limited)

Lallier C, 2011, “Film: La ville sur des rails - L’utopie de la métropole - Predit”, Objectif Images, http://www.predit.prd.fr/predit4/synthesePublication.fo?inCde=41588

Lavadinho S, 2009, “The multimodal walker. Potentials for combining walking and public transport at the agglomeration scale”, in STRC Conference Proceedings, 9 September 2009 (Ascona), p 17, http://marcherenville.net/upload/MARCHERENVILLE/pdf/46STRC09paper.pdf

Lavadinho S, 2011 Le renouveau de la marche urbaine: Terrains, acteurs et politiques, Ecole normale supérieure de lyon-ENS LYON, http://hal.archives-ouvertes.fr/tel-00737160/

Lefébure C, 2004 Croix et calvaires: chefs-d'oeuvre de l'art populaire (Flammarion, Paris)

Lennert M, Van Hamme G, Patris C, Smętkowski M, Płoszaj A, Gorzelak G, Pumain D, Comin MN, Gregor M, Rozenblat C, Angelidis M, Robert J, Fons J, Bozzani-Franc S, L’Hostis A, Ludlow D, 2010, "Future Orientations for Cities final report”, ESPON, http://www.espon.eu/main/Menu_Projects/Menu_AppliedResearch/foci.html

Le Scouëzec G ’hlan, Masson J-R, 1982 Pierres sacrées de Bretagne (Seuil, Paris)

L’Hostis A, 2014 Le détour, la pause et l'optimalité, Essai sur la distance et ses apports au transport et à l'urbanisme, Université Paris-Est, https://hal.archives-ouvertes.fr/tel01081570/

L'Hostis A, 2015, “Misunderstanding geographical distances: about three errors of interpretation of violations of the triangle inequality" Cybergeo : European Journal of Geography (accepted)

L'Hostis A, Alexandre E, Appert M, Araud-Ruyant C, Basty M, Biau G, Bozzani-Franc S, Boutantin G, Constantin C, Coralli M, Durousset M-J, Fradier C, Gabion C, Leysens T, Mermoud F, Olny X, Perrin E, Robert J, Simand N, Stransky V, et al., 2009, “Concevoir la ville à partir des gares, Rapport final du Projet Bahn.Ville 2 sur un urbanisme orienté vers le rail”, http://hal.archives-ouvertes.fr/index.php?action_todo=search\&view_this_doc=hal00459191\&version=1\&halsid=jberg3bims60tparrhqgnsh4j2

L'Hostis A, Leysens T, Liu L, 2015, “Contribution de la future ligne ferroviaire à grande vitesse Tours-Bordeaux au développement des réseaux des villes, une évaluation par le potentiel de contact” Cybergeo : European Journal of Geography, https://hal.archives-ouvertes.fr/hal01163644

Madanipour A, 1999, "Why are the design and development of public spaces significant for cities?” 
Marmonier C, 1999 Le grignotage : sa définition physiologique. Mise en évidence de ses conséquences métaboliques et comportementales à court terme chez l'homme, Paris 7, Paris, http://cat.inist.fr/?aModele=afficheN\&cpsidt=200910

Massot M-H, 1999, "Les pratiques de multimodalité dans les grandes agglomérations fran\ccaises” TEC 153 32-39

Menerault P, Stransky V, 1999, “La face cachée de l'intermodalité” Lyon Les Cahiers Scientifiques du Transport (35) 29-53

Monreal C, James P, Hudson C, Carroll-Bell S, Taing A, “The (Im) Mobile Life of Food and Drink Packaging Technologies in the City" whole or in part, must be clearly attributed to the author, http://global-cities.info/wp-content/uploads/2013/11/The-ImMobile-Life.pdf

Moody S, Melia S, 2013, "Shared space: Research, policy and problems”, in Proceedings of the Institution of Civil Engineers-Transport (ICE), http://eprints.uwe.ac.uk/17937/

Müller J-C, 1982, “Non-Euclidean geographic spaces: mapping functional distances” Geographical analysis 14 189-203

Offner J-M, 2010, “L’urbaniste ? Un ajusteur de distances” Urbanisme 5(372) 56-57

Perreur J, 1989, “L’Evolution des représentations de la distance et l’Aménagement du territoire” $R E R U(1)$

Richer C, Quetelard B, Meissonnier J, Rabaud M, 2012, “Quelle(s) intermodalité(s) dans les mobilités quotidiennes ? L’apport des Enquêtes-Ménages Déplacements (EMD) dans l'analyse des pratiques intermodales", in (Montpellier), http://www.cete-nordpicardie.equipement.gouv.fr/communications-recentes-a206.html

Roberts M J, Newton E J, Lagattolla F D, Hughes S, Hasler M C, 2013, “Objective versus subjective measures of Paris Metro map usability: Investigating traditional octolinear versus all-curves schematics” International Journal of Human-Computer Studies 71(3) 363-386

Roty T, 2000, “Conception et management de projets de pôles d'échanges : la question des parcours des usagers : La Défense, Massy, Val d’Europe”, DRAST, http://cat.inist.fr/? aModele=afficheN\&cpsidt $=103946$

Scanlan J, 2004, “Trafficking” Space and Culture 7(4) 386-395

Schmidt I, Collett T S, Dillier F-X, Wehner R, 1992, "How desert ants cope with enforced detours on their way home" Journal of Comparative Physiology A 171(3) 285-288

Simmel G, 1997 Simmel on Culture: Selected Writings (SAGE)

Sinnett D, Williams K, Chatterjee K, Cavill N, 2011, "Making the case for investment in the walking environment: A review of the evidence”, http://eprints.uwe.ac.uk/15502/1/Making_the_Case_Full_Report.pdf

Terrier C, 2006, “L’Économie présentielle. Un outil de gestion du territoire” Cahiers Espaces 906 
The Island in the Mur, 2014 http://www.graz03.at/, http://www.graz03.at/servlet/sls/Tornado/web/2003/content_e/8FCE673302F9BE61C1256B 81005CED38

Tobler W R, 1961 Map transformation of geographic space, University of Washington, Geography, Washington

Törnqvist G, 1970 Contact Systems and Regional Development (Royal University of Lund. Department of Geography)

Törnqvist G, 1973 Contact requirements and travel facilities: contact models of Sweden and regional development alternatives in the future

Turner A, Penn A, 2002, "Encoding natural movement as an agent-based system: an investigation into human pedestrian behaviour in the built environment” Environ Plann B 29(4) 473-490

Webster F V, Bly P H, Paulley N J, 1988 Urban land use and transport interaction; policies and models, http://trid.trb.org/view.aspx?id=1183782 